\title{
Lake Ousteri: An Artificial Wet Land Lagoon for Tourists in Puducherry
}

\author{
E. Devabalane* \\ Assistant Professor, Department of Tourism and Travel Management, Tagore Arts College, \\ Puducherry -605008, India; devabalane@gmail.com
}

\begin{abstract}
Wet land, are water bodies of different types ranging from lakes, estuarine area, riparian flood plains to tidal mud-flats, play a vital role in ensuring both the quality and quantity of water for human beings and the entire range of flora and fauna. It provide fresh water for agriculture, livestock and domestic consumption and recharge the ground water levels which are under immense strain of over-exploitation. Detailed economic studies on wetland tourism are not always available but the income from tourism can support the wise use of wetlands which in turn sustains tourism activities. The fact that environmental damage hurts people both today and tomorrow, if the future provides additional grounds for rethinking our measurement of progress towards sustainability. However ever increasing, multiple demands on water resources for agriculture, irrigation, domestic, industrial supplies have greatly impacted upon the ecosystems. Yet little attention is paid for the restoration, conservation and sustainability of wetland ecosystems which contribute significantly to the food security and economy of the local community. In Puducherry, well known wetlands are Ousteri and Bahour. During the year 2008, Ousteri wetland, largest lake in Puducherry was declared as a bird sanctuary, home for hundreds of species of migratory birds, variety of fishes, mussels and crabs, and breeding sites of common coot in South India. With this backdrop, the study deals with primary and secondary sources with survey methods on socio-economic and biological, flora and fauna parameters in and around the lake area for developing wetland tourism. Conservation and sustainable wet land tourism management is urgently required with appropriate institutional arrangements for sustainable development, implementation of policy, long term planning strategies with sustainable management action plan with a hope to achieve the objectives, with the help of community involvement.
\end{abstract}

Keywords: Wetland Tourism Management, Water Governance, Lake' Ecosystems, Planning Strategies, Bio-Physical, Anthropogenic, Food Security

\section{Introduction}

Tourists are naturally attracted to water, to coastal wetlands such as coral reefs and beaches and to inland wetlands such as lakes and rivers. This reflects strong bonds between people and nature as well as the unique aesthetic appeal of wetlands. Wet lands and wildlife are indeed a key part of the global tourism experience, from mass tourism to special interest tourism especially wetland tourism. In the present study, an attempt had been made that to know how natural resources like fresh water lakes can be protected for future generations. Wet lands are "lands transitional between terrestrial and aquatic eco-systems where the water table is usually at or near the surface or the land covered by shallow water" [1]. The wet lands retain the water during dry periods, thus maintaining the water table high and relatively stable. The removal of such wetlands in the name of globalization, urbanization and other human interventions can cause severe threat to such resources and supporting species diversity. Wet lands are areas of marsh, fen, peat land or water, whether natural or artificial, permanent or temporary with water that is static or flowing, fresh, brackish or salt, including areas of marine water the depth of which at low tide does

\footnotetext{
${ }^{*}$ Author for correspondence
} 
not exceed six meters, (Ramsar Convention [2]). In India, wetlands estimated to be 58.2 million hectares distributed in almost all bioclimatic regions are important repository of aquatic bio diversity. Puducherry, well known for water bodies especially wetlands consisting of 82 major and small located around Puducherry, provides livelihood for the local residents in the form of agriculture, fishing, fuel, fodder and other daily needs. In Puducherry there are two major wetlands like Ousteri and Bahour. In collaboration with the States and UTs since 1956 the Government of India has been implementing the National Wetlands Conservation Programme (NWCP). Under this programme, 115 wetlands had been identified (Anon [3]). In Puducherry, the ouster wetland had been selected and declared as wetlands of national importance and also as a bird sanctuary in the year 2008. The sanctuary is also known for a wide variety of fish, mussels and crabs. In the past the lake has also served as the largest breeding sites for the common coot in South India (Chari and Abbasi [4]). Recently the lake is facing serious threats and pressures from several anthropogenic activities like poaching, unsustainable fishing pollution. Encroachment, hunting of birds, dumping of solid wastes in and near the lake embankments, littering around the lake by tourists and local visitors, frequent vehicular movements by light and heavy motor vehicles, waste water discharge into the lake, and rapid urbanization, infrastructural developments in the vicinity of the lake, agro chemicals, pesticides, weed infestation and soil erosion needs that calls for an extensive field study which is the need of the hour for the sustainable development and strategies for effective ecological balance, and, at the same time to achieve the objectives of sustainable wetlands in Puducherry, particularly Lake Ousteri.

Pondicherry has a coastal boundary of length $8 \mathrm{kms}$ and breadth ranging from 5 to $6 \mathrm{kms}$. This region is a lowlying area and intersected by delta canals of the Gingee and Pennaiyar rivers and other streams. There are two important drainage basins of the Gingee river and Pennaiyar river in the region. The Gingee river crosses Pondicherry region diagonally from northwest to southeast and the Pennaiyar river forms the southern boundary of the region, the Gingee river has a course of $34 \mathrm{kms}$ in this region with its source at Malayanur village of Cuddalore district in Tamil Nadu. It shoots into two branches known as the Ariankuppam river and the Sunnambar river at a distance of $7 \mathrm{kms}$ from its mouth. Anicuts have been constructed across these rivers for collection and its right side. Of these affluent the Pambayar and the Kuduvaiyaru alone flow in Pondicherry.

There cannot be a better place for bird-watchers in the Union Territory other than the Ousteri Lake. The bird sanctuary is $10 \mathrm{kms}$ away from Pondicherry. You can see birds that have migrated from northern and central Eurasia. Easter fowls, cranes, eagles hawks are some of the rare birds nesting in the sanctuary. This is a cool spot for picnics. Children's play area, two watchtowers and a restaurant near the lake would make it a pleasant outing for the whole family. In fact it can be treated as a lagoon for both domestic and international tourists is not an exagerration.

\section{Back Ground of the Study}

Wet lands provide many services and commodities to humanity. Wet lands perform numerous valuable functions like recycling nutrients, purifying water, maintain stream flow, restore ground water level, attenuate floods, providing potable water, fish, fodder, fuel, wildlife habitat, buffer shorelines, leisure, recreation, tourism activities to the society and local community. Wet lands are considered as "Kidneys of the landscape (Gosselink and Mitsch [5]). According to Kusler [6] even limited wetland related facilities may play an important role in meeting regional needs. Wetlands loss refers to physical loss in the spatial extent or loss in the wetlands function. The loss of one $\mathrm{Km}^{2}$ of wetlands in India will have much greater impact than the loss of one $\mathrm{Km}^{2}$ of wetlands in low population areas of abundant wetlands (Foote et al [7]). The demand for wetland products will increase with increase in population. But the fact that the wetland products are overlooked has resulted in a threat to the resource and benefits which finally results in the degradation of wetlands. Realizing the importance of wetlands, the Ramsar Convention [2] has urged their member countries to designate noted wetlands as Ramsar sites or wetlands of international significance. Many conservationists recognized this and a wetland conservation strategy should therefore have an extensive bias of participatory process Choudary [8]. Garther [9] had identified that the cumulative efforts over time are particularly problematic because the developer in question is often out of the picture before impacts become obvious (Butler [10]), has opined that sustainable tourism has to be developed and maintained in an area (environment, community) in such a manner and at such a scale that it remains viable over an indefinite period and does not degrade or alter the environment (human, physical) in which it exists to such a degree that it prohibits the successful development of wellbeing of other activities and processes.

Ousteri lake is situated near the village Ossudu, at $11^{\circ} 57 \mathrm{~N}, 79^{\circ} 45 \mathrm{E}$, partly in Puducherry and Tamil Nadu state. Whereas much of the Ousteri lake is located in Tamil Nadu, which consists of rural settlements and in 
Puducherry the lake is predominantly suburban. Ousteri lake is the largest fresh water lake of Puducherry region, covering some 700 hectares when full after a normal monsoon. It can store 540 million cu. $\mathrm{ft}$ of water, capable of irrigating close to 3800 hectares of land (Abbasi [11]). According to the legend, in recognition of Oosi's selfless service, the lake was named Oosteri which in due course of time rechristened as Ousteri. The resulting lake had $7 \mathrm{kms}$, circumference and $15 \mathrm{~km}^{2}$ of catchment area. During the rainy season, the lake would appear like an ocean with a vast span of bluish water (Eshwar [12] ).

\section{Objectives}

- To estimate the current status of the lake.

- To study the motivation level of the tourists.

- To develop appropriate strategies for wet land tourism in Puducherry.

\section{Methodology}

The methodology adopted during the study is through the primary and secondary sources. The primary data is collected through survey technique by preparing questionnaire .Apart from this the community interaction is conducted, so that their perception and attitude towards the lake is also identified. The study period is short in duration, five months Jan-May 2013, hence an in depth analysis of the study has its own limitation. More than 123 samples had been tested with the questionnaire, but 100 respondents had been taken for the study.

\section{Profile of the Study Area}

In the study area, and its environs, among 480 species, 191 herbaceous plants are available (41\%), 103 tree species (21\%), shrubs 63 species (13\%), climbers 40 species (8\%), stragglers 20 species (4\%) and grasses 63 species are available $(13 \%)$ in and around the lake Ousteri. Of the 480 species 11 are found to be endemic (Andropogon pumilus, Asystasia dalzelliana, Barleria acuminata, Cynodon barberii, Drypetes roxburghii, Iseilema anthephoroides, Jatropha tanjorensis, Maba buxifolia, Phyllanthus rotundifolia, Sarcostemma brunonianum and S. intermedium) are distributed only in the Indian sub continent, (Henry et al. 1978, Ahmedullah and Nayar [13], Nayar [13]. More than 20 species found to be on the endangered list have medicinal values. Ousteri is not only rich in flora but also in fauna. It has become a major attraction for tourists and visitors to the lake for watching butterflies, amphibians, reptiles, birds, mammals.63species of butterfly under 46 genera and spreads over 5 families, Nymphalidea is dominant one 21 species (34\%), followed by Pieridae with 14 species (22\%) and Lycaenidae 10 species $(16 \%)$. Wet lands like Ousteri, has become a resting site for migratory birds and the lake Ousteri is declared as a bird sanctuary due to its wealth of Avifauna, 166 species of birds belonging to 47 families were recorded and spotted in the lake zone both of terrestrial and acquatic habitats. Of the 47 families, Muscicapidae is the dominant one with 16 species and followed by Accipitridae (12 species), Ardeidae (11 species) and Anatidae (10 species).Of this 166 species, Spoon-billed sandpiper is "Critically endangered" and White-bellied Sea Eagle comes under the category of "Endangered". Apart from these, birds such as Flamingos, Darter, Spot-billed Pelican, Great white Pelican, Painted Stork, Eurasian Spoon Bill and Pallid Harrior are coming under near Threatened category (Balasubramanian and Vijayan [14]). The lake and its surroundings are rich in Amphibians 10 species like cricket frog common Indian toad, Indian bull frog and 29 reptile species are recorded which includes turtles, lizards, snakes. 25 species of fish is available in the lake. Species such as Catla catla, Mystus vittatus, Heteropneustes fossilis, Channa orientalis, Clarias batrachus, Etroplus suratensis and Mystus gulio are vulnerable species. Two species namely, Channa striatus and

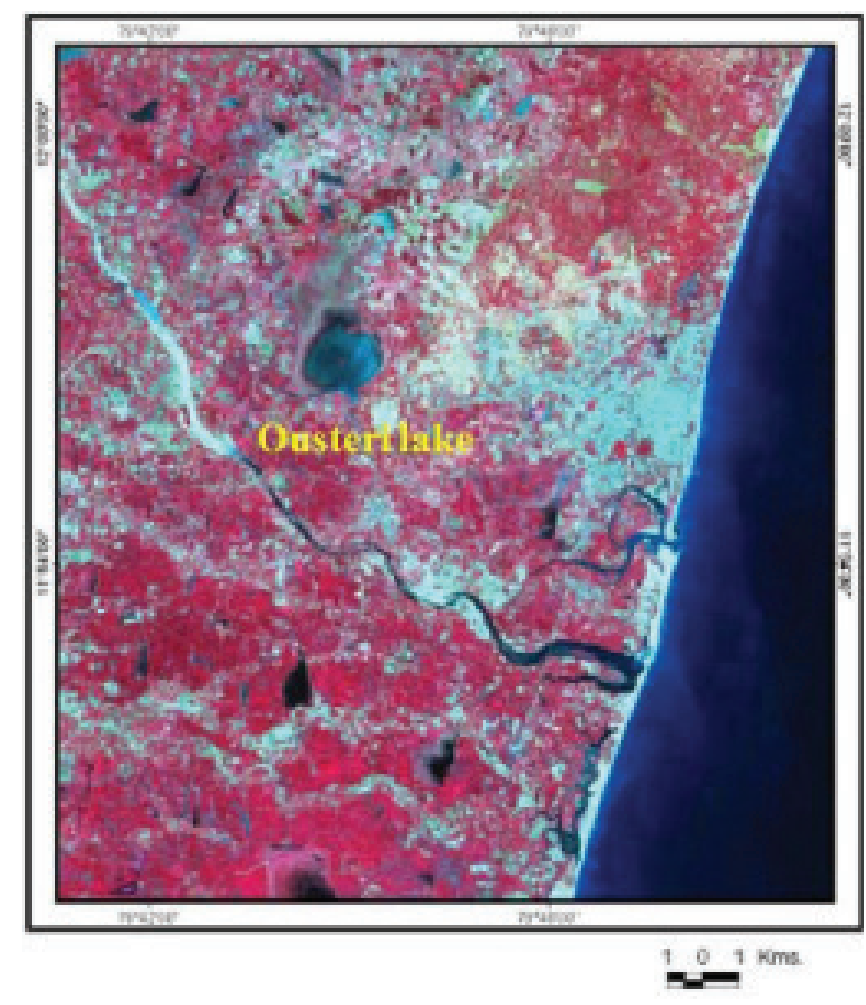

Figure 1. IRS IC LISS III satellite imagery of the study area (Source: Nobi et al. 2009).

HuSS: International Journal of Research in Humanities and Social Sciences 


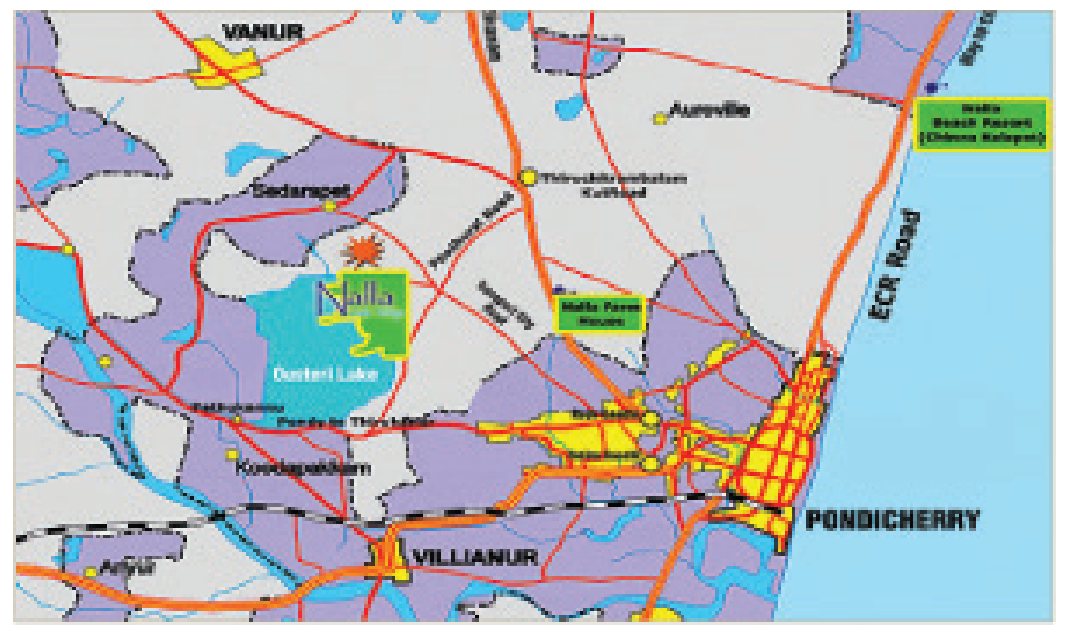

Figure 2. Classified Land use/Land cover map of the study area (Source: Nobi et al. 2009).

Gambusia affinis are falling under Low Risk - least concern category. Three species viz., Oreochromis mossambica, Cyprinus carpio and Hypophthalmichthys molitrix are exotic. Rest of the 10 species are included under less risk category. 14 species of Mammals are also available in and around the lake jurisdiction. Species such as spotted deer, Jackal, Jungle cat, common mongoose, Black napped hare, Bonnet macaque, Indian porcupine, Bandicoot rat, Three stripped palm squirrel, Indian pangolin, Asian palm civet, Mice, Short nosed fruit bat, Flying fox.

The study is based on the primary data collected from the respondents and interaction with the population living near the lake. More than 21 villages are dependent directly and indirectly by the lake for several reasons of their own especially for their socioeconomic benefits. The lake is useful to the people in several ways for providing namely, Potable water, irrigation, recharging ground water level, climate regulation, pollination, water regulation, natural hazard regulation, commercial fishing, fodder and grass for cattle's, grazing, desilting, reed cutting, recreational tourism, and other leisure activities.

\section{Infrastructure for Wet Land Tourism}

Tourism infrastructure is the essential requirements for the development of wet land tourism in Puducherry. The facilities is not adequate for the tourists, though the site is well connected by roads, $10 \mathrm{Km}$ distance from Airport and railway station. A well planned infrastructure should be put in place near the lake area which is very much required to attract lot of tourists. Before creating. Infrastructure the other basic amenities should be created like toilets, parking places, bird watching tracks, camping grounds, picnic zones, children's playground, walking and cycling trails. Since it has been an important bird sanctuary, tourists can stay for a while to watch varieties of birds from multiple countries. To satisfy their needs standard and supplementary accommodation can be created like resorts, lake view hotels, green hotels. The present infrastructure is not sufficient to accommodate more number of tourists, due to lack of minimum facilities. So the need of the hour is to facilitate with recreational facilities like cafes, restaurant's, bird watching trails, binoculars and boating facilities with minimum pollution to the lake keeping in view the sustainability factor of the lake area.

\section{Analysis and Interpretations}

Tourism is considered to be an important service sector in Puducherry. Its location on the Bay of Bengal Coast with its French historical past and spiritual attractions attracts lot of domestic and foreign tourists to the region. The statistics of the tourists visiting the region is exhibited in the Table 1.

\section{Distribution of Respondents based on their Purpose of Visit to Puducherry}

There should be some motivating factor for the tourists to visit some places of interest. The reason for visiting certain places may be different for different travellers. Here the distribution of both domestic and international tourists across their purpose of visit has been analysed.

From the results presented in the above table (Table 1.), it can be understood that $49 \%$ of the domestic tourists and 
26.5\% of international tourists were visiting Puducherry for 'pleasure'. Tourist visiting just for sightseeing account for $21 \%$ for domestic and $27 \%$ for international travellers. Making trip to Puducherry the purposes others than above, such as Health, Sports, Business, Spiritual, Pilgrimage, were very dim.

At the same time visiting Pondicherry by International for the purpose of Business, Spiritual and Sociological as well as for study were higher compared to their counterparts, domestic visitors. Further, it is seen from the

Table 1. Tourist Arrival Statistics of Puducherry

\begin{tabular}{lccc}
\hline Year & Domestic & International & Total \\
\hline $2001-02$ & 527274 & 23878 & 551152 \\
$2002-03$ & 476804 & 22115 & 498919 \\
$2003-04$ & 480552 & 20094 & 500616 \\
$2004-05$ & 500139 & 25559 & 525698 \\
$2005-06$ & 558445 & 32053 & 590498 \\
$2006-07$ & 574011 & 36009 & 610020 \\
$2007-08$ & 652245 & 46273 & 698518 \\
$2008-09$ & 798528 & 57682 & 856210 \\
$2009-10$ & 827799 & 60309 & 888108 \\
$2010-11$ & 856766 & 64321 & 921097 \\
\hline
\end{tabular}

Source: Department of Tourism. significant coefficient of contingency $(0.3278, \mathrm{p}<0.01)$ that the purpose of visit differs markedly between domestic and international tourists.

\section{Distribution of the Respondents based on Motivation to Visit}

There should be some factors that motivate the tourists to travel to a particular destination of tourism importance. People can undertake a trip to any destination if it is of religious and spiritual or cultural and heritage importance. Some places can be visited by tourist either to have contact their nostalgic relationship or simply for entertainment and recreation. Therefore, there should be some motivating factors behind every traveller. In this scenario, an attempt has been made here to analyse few factors that is considered to be motivating the domestic and international tourists to undertake a trip to Pondicherry.

It is observed from the table (Table 3.) that recreation, leisure, bird watching' is the major motivating factor for both domestic and international tourists. $39.5 \%$ of domestic tourist and $28 \%$ of international tourists visited this city just for recreation, leisure and bird watching. This is followed by 'Religious and spiritual' for domestic front (29.5\%) and 'cultural and heritage' for international tourists $(23 \%)$ as the motivation to visit. Next to the above, $21 \%$

Table 2. Distribution of tourists on the basis of purpose of visit to Puducherry (in percentage)

\begin{tabular}{lccc}
\hline Purpose of Visit & Domestic Tourists & International Tourists & Total \\
\hline Pleasure & 49.0 & 26.5 & 37.8 \\
Sports & 2.0 & 2.0 & 2.0 \\
Health & 3.0 & 2.5 & 2.8 \\
Business & 3.0 & 12.0 & 7.5 \\
Adventure & 0.5 & 2.0 & 1.3 \\
Archaeological & 1.5 & 1.5 & 1.5 \\
Seminar & 5.5 & 5.5 & 5.5 \\
Spiritual & 4.0 & 5.0 & 4.5 \\
Sociological & 1.0 & 7.0 & 4.0 \\
Religion & 21.0 & 27.0 & 24.0 \\
Study & 4.0 & 7.5 & 5.8 \\
Pilgrimage & 2.0 & 0.0 & 1.0 \\
Recreation/Leisure/Bird & 2.5 & 0.0 & 1.3 \\
Watching (Wetland Site) & & & \\
Culture & 1.0 & 1.5 & 1.3 \\
Total & 100.0 & 100.0 & 100.0 \\
Coefficient of Contingency & 0.3278 & Significant @ 1\% level. \\
\hline Source: Primary Data. & & &
\end{tabular}


Table 3. Percentage Distribution of Tourists on the Basis of Their Motivation to Visit Puducherry

\begin{tabular}{lccc}
\hline Motivation to Visit & Domestic Tourists & International Tourists & Total \\
\hline Religious and Spiritual & 29.5 & 12.0 & 20.8 \\
Cultural and Heritage & 21.0 & 24.0 & 22.5 \\
Nostalgic Relationship & 6.0 & 23.0 & 14.5 \\
Recreation/ Leisure/Bird & 39.5 & 28.0 & 33.8 \\
watching (wetland site) & & & \\
Others & 4.0 & 13.0 & 8.5 \\
Total & 100.0 & 100.0 & 100.0 \\
Coefficient of Contingency & 0.3290 & Significant @ 1\% level. \\
\hline
\end{tabular}

Source: Primary Data.

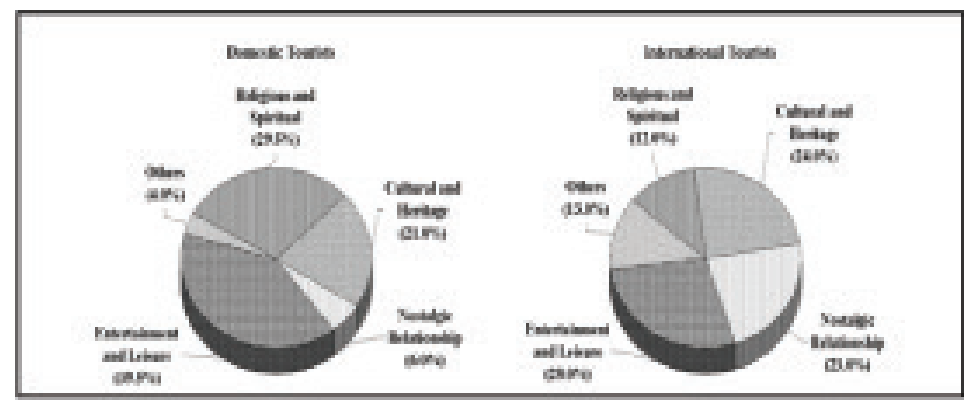

Figure 3. Distributions of respondents based on the motivation to visit.

of the domestic tourists were motivated to visit to this place due to its cultural and heritage importance while $23 \%$ of the foreigners visited Pondicherry with motivation of seeing their nostalgic relationship. At the same time, factors that motivating for making a trip to Puducherry seems to be differing between domestic and international tourists as the calculated coefficient of contingency $(0.3290, \mathrm{p}<0.01)$ is significant Visual representation of the above distribution is given using Pie diagram (Figure 3).

\section{Findings of the Study}

$1.3 \%$ of tourists prefer to visit Puduchery as a recreational spot to visit natural attractions like beaches, lakes, wetlands especially lake Ousteri.

$39.5 \%$ of domestic tourist and $28 \%$ of international tourists visited this city just for recreation, leisure and bird watching.

$44 \%$ of people say that Mono culture cropping is practiced especially in paddy and sugarcane, casuarinas, coconut, teak.

$21 \%$ says the lake is the only livelihood for them, $33 \%$ opines that their alternative livelihood is self employment, entrepreneurship, livestock rearing, 24\% started practicing poultry farms, aqua culture, $55 \%$ of the farmers around the lake are involved in organic farming instead of fertilizers, they are using eco friendly manures like dried cow dung, azospirillum, vermicompost, phosphobacteria, $12 \%$ of the nearby population uses the lake for potable purpose, $23 \%$ of the population use for agriculture by irrigation, $16 \%$ of the populations are involved in direct fishing from the lake, $10 \%$ are involved in hunting and poaching birds (pelicans, coots, darters, and frog).

\section{Lake Management}

The competent authorities should undergo the following guidelines: To prepare overall strategies for tourist destinations based on the dialogue with the private sector, local bodies and NGO's with a vision for future. To participate in the enhancement and management of tourist destinations, balancing the interests of the environment with those of residents, tourists, and tour operators. Launch campaigns to inform the tourist's communities (service providers and tourists) about the advantage of embarking on strategies and action plans for wet land tourism. Involve local leaders in wetland ecosystem and resource conservation planning efforts which help them to understand the linkages between tourism, resource protection and economic advantages. To hold migratory 
bird festivals, wet land festivals which highly visible economic benefits to the local community. To collect economic data concerning the value of wet land tourism locally. To provide wet land tourists card at the wetland site to protect and conserve birds and community. Construct roads and interpretative facilities adjacent to the wetland by establishing buffers and setback where possible. To provide bird watching trails adjacent but not into wetlands by using elevated platforms for viewing the lake by arranging guided walks and boat tours (leisure boats), and by creating bird watching observatory with the essential equipments. To limit the negative interaction between mechanized or harsh sound making activities for sustaining the stability of the wet land ecosystems. To ensure the sustainability of the natural resource base, the recognition of all the stake holders in it and their roles and responsibilities in its protection and management is essential. The traditional approaches to natural resources management in lakes water harvesting and management system should be revived by creating institutional mechanism with ecological wisdom and the spirit of community management inherent. Lake Clean Development Mechanism strategy (L.C.D.M.), can be achieved by providing financial assistance to sustainable development programmers with clear-cut objectives. User community pyramid strategy by using integrated and appropriate technological solutions and the applications thereof for the success of the sustainable development of the people. Change in life style of the citizen should go a long way to attain sustainable development and water bodies' conservation. Landscape beauty for the lake's scenic view, space for tourism, recreation and for the local residents with few entrances, to the wet lands is very much required.

\section{Discussion}

Ousteri is unique wetlands in South India rich in diversity and bird life, providing food and shelter as also the breeding and spawning ground for the fresh water fishes. But the excessive use of fertilizers and pesticides impose threat to local population and to the genetic stocks of the water bodies, which reduces the natural soil fertility in long run. Water table is receding because of over use of ground water in the surrounding areas of the lake. Large numbers of industries and other development projects have been resulted to pollution of water bodies, which is an undesirable phenomenon for the fresh water lake ecosystem.

To conclude, development of lake tourism has to be sustainable and all round, whether for the poor, village folk, urban people, the sustainable development models have to be reviewed and followed. Promotion of wet land tourism should be based on careful assessment of the carrying capacity and support facilities without affecting the lifestyles of the local people, for achieving sustainability. Strengthening local bodies, panchayats, samitis, for optimal resource management and contingency plans is advisable for micro level planning. Social forestry, land use planning, afforestation, watershed management through catchment treatment of drainage areas, protection of vegetal cover, fishing activities fully accountable, environmental sanitation, GIS Tools for monitoring, strengthening enforcement machinery, and the importance of water bodies renewable resource should be recognized. Therefore the task of wet land tourism development is never daunting if people's movement of concern over environment, the media, public, youth and children is vigil and effective, and can make this beautiful lake Ousteri recognized as a lagoon of Puducherry, an artificial water body created during the French regime in Puducherry can be in the international map of Ramsar, as an important must see wetlands of the world.

\section{References}

1. Mitsch W.J., Gosselink J.G., Wetlands, 3rd ed, New York: John Wiley and Sons, 2000.

2. IUCN, The Ramsa Convention, "The Final Act of the International Conference on the Conservation of Wetlands and Waterfowl", IUCN Bulletin, vol. 2(Spl. Supplement), pp. $1-4,1971$.

3. Anon, "National Wetland Conservation Programme Guidelines for Conservation and Management of Wetlands in India", Ministry of Environment, Govt. of India, New Delhi, 2009.

4. Chari K.B., Abbasi S.A., "Ecology, Habitat and Bird Community Structure at Ossudu lake: Towards a strategy for Conservation and Management". Acquatic Conservation: Marine Fresh Water Ecosystem, vol. 13, pp. 373-386, 2003.

5. Gosselink., Mitsch., Wetlands, $2^{\text {nd }}$ ed, New York: John Wiley and sons, Van Nostrand Reinhold, 1986.

6. Kulser, "Sustainable utilization of water resources I watershed prespective - A case study of Alunja water shed", Journal of Indian Society of Remote Sensing., Vol. 27, pp. 13-23, 2006.

7. Foote L., Pandey S., Krogman N.T., "Processes of Wetlands loss in India”, Environmental Conservation, vol. 23, pp. 45-54, 1996.

8. Chouldry B. C., "Conserving Wetlands: Emerging Scenario". Proceedings of the workshop on the conserving biodiversity in the $21^{\text {st }}$ century through integrated conservation and development planning on a regional scale, Mussorie, Dehradun: WII, LBSNA, pp. 131-138, 2000.

9. Garther W.C., "Tourism development: principles, processes, policies", 1996. 
10. Butler R., “Tourism - an evolutionary prespective”, Tourism and sustainable development: monitoring planning and managing, Ontorio, pp. 77, 1993.

11. Abbasi., Ecology, habitat and bird community structure at Ossudu lake towards a strategy for conservation and management, Aquatic conservation, marine fresh water ecosystem., vol. 13, pp. 373-388, 1997.

12. Eswer., Environmental Governance in India - a concept note, Mumbai: Lead India-2, IGIDR, 2006.

13. Henry., Ahmedullah, Nayar, et al., "Rare and threatened flowering plants of South India", Journal of Bombay Natural Science., vol. 75 pp. 695-696, 1978.

14. Balasubramanian, Vijayan, "Conservation strategies and action plans for the avifauna of Tamil Nadu", Tamil Nadu biodiversity strategy and action plan, pp. 76-79, 2004.

\section{Other References}

1. WTO, "World Tourism Organization", Guide for local authorities on developing sustainable tourism. Madrid, 1998.

2. Abbasi S.A., Chari K.B., Environmental management of urban lakes: with special reference to Oussudu, New Delhi: Discovery Publishing House, pp. 269, 2008.

3. Alexander R., Pushparaj P., "Resettlement of weaver birds (Ploceus philippinus) in Ouster lake", Current Science, vol. 99(1), pp. 10, 2010.

4. Anon, A Dictionary of Wetlands in India, Ministry of Environment, Govt. of India, New Delhi, 1990.
5. Van Nostrand Reinhold, Kusler, J.A., Common Questions, wetlands and Eco tourism, New York, USA: Association of State Wetland Managers, inc., 2006.

6. Turner R.K., "Economics and Wetland Management", Ambio, vol. 20, 1991.

7. Zimmermann, World resources and industries, London: Harper and Row, 1951.

8. Gosselink J.G., Turner R.E., The role of Hydrology in fresh water wetland ecosystem, New York: Academic Press, pp. 63-78, 1978

9. Ramsey E.W. III, "Monitoring flooding in coastal wetlands by using radar imagery and ground based measurements", Int J Rem Sens, vol. 16, pp. 2495-2502, 1995.

10. Vijayan V.V., "Keoladeo National Park Ecology Study, Final Report", Bombay Natural History Society, 1991.

11. Kalam A.P.J., "Sustainable Development Initiatives", The Hindu, pp. 5, 16 Dec 2012.

12. Levine, Stephan, Khehbiel, Berenson, Statistics for Managers using Microsoft Excel, 5th ed, PHI, pp. 56-69, 2009.

13. Available: http.1.www.ramsar.org/info/values_ groundwater_e.htm

14. Available: http.2.www.ramsar.org/info/values_sediments_e. htm

15. Available: http.3.www.ramsar.org./info/values/ biodiversity_e.htm

16. Available: http.4.www.geography fieldwork.com 